Vol. 3, nº 1 | 1999

Varia

\title{
Weak Bodies? Prostitutes and the Role of Gender in the Criminological Writings of 19th-century German Detectives and Magistrates
}

Peter Becker

\section{CpenEdition}

Journals

Electronic version

URL: https://journals.openedition.org/chs/935

DOI: $10.4000 /$ chs. 935

ISSN: 1663-4837

\section{Publisher}

Librairie Droz

\section{Printed version}

Date of publication: 1 January 1999

Number of pages: $45-69$

ISBN: 2-600-00356-8

ISSN: 1422-0857

\section{Electronic reference}

Peter Becker, "Weak Bodies? Prostitutes and the Role of Gender in the Criminological Writings of 19th-century German Detectives and Magistrates", Crime, Histoire \& Sociétés / Crime, History \& Societies [Online], Vol. 3, n | 1999, Online since 29 April 2009, connection on 22 March 2022. URL: http:// journals.openedition.org/chs/935; DOI: https://doi.org/10.4000/chs.935 


\title{
Weak Bodies?
}

\section{Prostitutes and the Role of Gender in the Criminological Writings of 19th-century German Detectives and Magistrates}

\author{
Peter Becker ${ }^{1}$
}

\begin{abstract}
The change in the representation of deviance, which took place during the second half of the $19^{\text {th }}$ century, is analysed in the writings of two groups of authors from German-speaking countries: criminalists (police experts and detectives) and criminologists (scholars in the fields of law, medicine and anthropology). My analysis of the representation of prostitutes reconstructs two master-narratives, which structured the reflection and writing on crime and deviance. Each of these created specific fears and anxieties related to prostitutes and affected the ways institutional responses to these fears were organized. I argue that the analysis of these narratives as part of a discursive practice provides a better understanding of the ways in which experts as well as lay people approached social problems, from both an intellectual and an institutional standpoint.
\end{abstract}

Le changement dans la représentation de la déviance qui se produisit au cours de la deuxième moitié du XIXe siècle est analysé à travers les écrits de deux groupes d'auteurs de pays germaniques: les criminalistes (experts de police scientifique et technique et enquêteurs) et les criminologues (universitaires dans les domaines du droit, de la médecine et de l'anthropologie). Mon analyse des représentations de la prostituée permet de reconstituer deux matrices du discours qui structurent les réflexions et les écrits relatifs au crime et à la déviance. Chacune d'elles suscite des craintes ou des angoisses propres et influence la réaction institutionnelle qu'elles déclenchent. Ma thèse est qu'en analysant ces écrits, en tant que pratiques discursives, on accède à une meilleure compréhension de la façon dont les experts, tout comme les profanes, approchaient les problèmes sociaux, d'un point de vue à la fois intellectuel et institutionnel.

\section{GENDER IN CRIMINOLOGICAL WRITINGS: THE CASE OF PROSTITUTES}

$\mathrm{W}$ hen the Italian criminologist, Cesare Lombroso, condemned women to a childlike state on the basis of his anthropological research, he pointed out that women in their retrogression usually did not turn to criminality but rather to prostitution: «...the born female criminal is, so to speak, doubly exceptional, as a

1 Peter Becker is professor of Central European History at the European University Institute. His main research interests are in the fields of the history of sexuality, police and criminology from the $18^{\text {th }}$ to the early $20^{\text {th }}$ centuries. His new project is a comparative analysis of bureaucracy from a cultural historical view point. His main publications are: Leben und Lieben in einem kalten Land (1990); Randgruppen im Blickfeld der Polizei, Archiv für Sozialgeschichte, 1992, 32; Une sémiotique de 
woman and as a criminal. For criminals are an exception among civilized people, and women are an exception among criminals, the natural form of retrogression in women being prostitution and not crime. The primitive woman was impure rather than criminal ${ }^{2}$. Even though Lombroso - and after him scholars such as Otto Weininger ${ }^{3}$ - were among the first to express the stereotypical description of women as mothers and whores in scientific terms, they also took up the long-existing notion that female deviance was closely related to sexuality.

It was this that enabled criminologists at the turn of the century to provide a scientific explanation for a worrisome detail in moral statistics, namely the low absolute and relative numbers of women committing crimes and misdemeanors, which seemed - at first sight - to threaten the moral supremacy of their male compatriots ${ }^{4}$. Even though moral statistics made gender-specific criminality rates more visible, criminologists played down the relevance of the low rate of female criminality by citing the results of their own observations about the lifestyles of women. They suggested that different living conditions, levels of education, and women's lack of physical strength caused this low level of criminality without giving women a higher moral capability ${ }^{5}$. Lombroso went one step further and identified the «real» deviant drives in women as sexual dissoluteness and was therefore able to include prostitutes among the female «criminals», who thus suddenly began to outnumber their male counterparts. In doing so, Lombroso transmuted the practical knowledge of early criminalistic writers, i.e. that female deviance would have shown up first as sexual dissoluteness, into a scientific truth.

Throughout the nineteenth century, female dissoluteness was important as an explanation of the persistent nature of the problem of male criminality. This can be seen in the writings both of scholars from various disciplines and of authors with practical experience in dealing with criminals, such as magistrates, detectives, and criminologists. Faced with the failure of bourgeois society to achieve a society free of crime and social problems, these authors, whom I will call «criminalists » for want of a better term, laid the blame for this defective development of society on the moral shortcomings of an increasing number of men. From their perspective, male citizens betrayed the prospects of bourgeois society and decided more frequently to take a wrong approach to life, with serious consequences for the well-being of the social body. Criminalists understood this decisive turn in the life of a citizen as a willful and conscious replacement of ethical principles by a faulty rationality - a decision which took place long before criminal acts were actually committed.

It was a commonly held truth that this wrong approach to life could be chosen quite late in an individual's development, as late as early adulthood. Criminological writers were eager to point to outside influences which lured young men into deviance: alcohol and dissolute women were among the most prominent factors.

l'escroquerie, Déviance et Société, 1994, 18; The triumphant advance of degeneration, in Sakai, S., et al., Medicine and the Law, 1998. I would like to thank the many people who commented on earlier drafts of this paper. I am particularly indebted to the three anonymous readers of Crime, Histoire \& Société/Crime, History \& Societies for their helpful and thoughtful suggestions.

2 Lombroso, Ferrero, (1895, 151ff).

3 Weininger $(1903,281 \mathrm{ff})$.

4 This was certainly not true for some exceptional crimes such as infanticide, which was committed by a higher percentage of women. Cf. Quetelet $1869,288 \mathrm{ff}$.

s Cf. Aschaffenburg (1903, p. 127ff) and Quetelet (1869, p. $291 \mathrm{ff})$. 
German teacher, Jakob Friedrich Abel, used this configuration in an exemplary manner in his account of the life of Friedrich Schwahn - a well-known criminal of the second half of the eighteenth century. Abel was interested primarily in the psychological dynamics that had turned an ordinary citizen's son into a famous rogue. As a result of his inquiry, Abel blamed Schwahn's parents for the way they had raised their son, asserting they had been too lenient and had not drawn moral and ethical boundaries around the maturing young $\operatorname{man}^{6}$.

This was, however, insufficient to produce such an outstanding criminal career, and Abel further attributed this career to the evil influence of a woman. Her attractive looks and her boundless sexuality appealed to Schwahn's strong drives. She used her sexual attraction to pull Schwahn into the world of rogues and thieves, and to keep him there by undermining his recurring feelings of remorse. Abel's story is representative of a criminological reasoning that had prevailed since the late eighteenth century, and in which women were often blamed for young men's drift into a criminal career?

This configuration, female seduction and victimization of the male, was not the only element in the narratives concerning the relationship between the two sexes; however, it dominated early criminological writers' narratives of the hidden motives of a man's descent into the criminal underworld. The way in which this configuration was used to address anxieties about men and their place within society depended both on commonly held anthropological theories and on the master narratives about men and their reasons for committing criminal acts. In the following, I will first use the discussions about prostitution in order to trace the ways in which professional and anthropological knowledge informed each other in the criminalist's attempts to describe and combat a criminal underworld. Secondly, I will present two models of thinking about criminals within bourgeois society and the attitudes of each towards prostitution.

\section{A PROFESSIONAL'S VIEW OF PROSTITUTES}

During the nineteenth century, German-speaking authors differed little from their English and French counterparts in the ways in which they addressed the social problem of prostitution. They all expressed their fear of a moral and physical contagion that they associated with prostitutes. There was one principal difference, however. Participation in German and French debates was not restricted to social scientists, medical experts, philanthropists, and military planners, as was the case in England ${ }^{8}$. In Germany and France, the existing regulations concerning prostitution gave police experts an incentive to take an active part in this discussion. Police experts shared a common interest and a common methodological approach with medical experts and moral reformers. Each of these groups was driven by a desire to develop new strategies for preventing any further moral and physical contagion of bourgeois society.

\footnotetext{
$6 \quad$ Cf. Abel (1794).

1 Merker (1839, p. 37).

8 Cf. Walkowitz (1980).
} 
There is, however, one aspect which gives the reflections of police experts a special place among the narratives on prostitution: Police experts were the only ones who claimed to have comprehensive and expert knowledge about the cultural and social dynamics of the world of prostitution and particularly about the lives and careers of prostitutes. In their reflections, police experts tried to integrate personal as well as communicated experience into a narrative that was built on the same moralethical stereotypical image of the prostitute which shaped the arguments of moral reformers. In addition, police experts shared with moral reformers the fear of prostitution as one of the most dangerous moral contagions.

The police were expected to combat this threat through prevention. This approach fits neatly with the general task of the continental police, which was to prevent rather than to solve crimes. As a precondition for successful preventative strategies, police experts, like the senior detective, Johann Friedrich Carl Merker, urged the collection of a body of knowledge on the world of thieves and « whores »? For a variety of reasons, police experts and magistrates felt compelled to publish their reflections on the causes of crime and destitution, which contributed to the expert knowledge about the lives and habits of people in the criminal underworld.

Until the end of the nineteenth century, authors of studies on prostitution did not restrict their inquiries to the application of quantitative methods, they also studied prostitution from an ethnographic and/or medical point of view. Their approach was ethnographic in that they saw themselves entering a strange and foreign culture that they wanted to decode in order to destroy. The strangeness and otherness of prostitutes lives as a part of the criminal underworld justified the police experts' claim to an exclusive understanding of its dynamic. The hidden secrets of this world revealed themselves in their totality only to the trained eyes of experienced detectives. At least this was what the detectives maintained. The lack of statistical refinement in these studies was, however, not only a consequence of this but resulted also from their resistance to a genuine materialistic approach and of their rejection of a restricted understanding of evidence as empirical facts ${ }^{10}$.

While the attitude of police experts towards prostitutes, as a field of investigation, was ethnographic, their analytic approach was influenced by traditional medical semiotics. Medical semiotics structured the way in which police experts tried to decipher the hidden causalities behind prostitution. It was understood as a disease of the social body and its visible manifestations were therefore read as symptoms of a disease which surfaced on the body of the patient, i.e. society. While the authors used medical models to decipher the symptoms of social pathology, the signs were taken from ethnographic observations of the criminal underworld.

The way police experts looked at prostitution very much affected the outcome of their analysis. Police experts described their approach to all kinds of social problems with the term «practical view » (praktischer Blick), which appeared both in medical and in criminalistic writings on methodology. This view referred to the attempt by detectives and physicians to access hidden causalities with an intuitive, yet focused

\footnotetext{
9 Merker (1839, p. 4ff).
}

10 Bon $B(1982$, p. 104ff) argues that this understanding of evidence was representative of early social scientific studies. 
and learned interpretation of visible clues. «Certainly experience, a trained practical view, tact and refinement are required...», which was how Magistrate F.A. Wennmohs, from Mecklenburg, described the profile of a successful detective ${ }^{11}$.

In the case of police experts, they claimed that their practical view allowed them to reproduce a highly selective, but nevertheless authentic image of the observed social realities ${ }^{12}$. The visible indications of prostitution as a social problem were deconstructed and used to access its hidden order. Order was the key term in all these methodological enterprises. Every social reality was believed to have its own order. To understand the criminal underworld, the detectives had first to figure out its genuine order. To accomplish this task, observers had to employ not only their practical view, they had to adhere to a set of rules, such as impartiality and causality. Based on their experience, training, and authority as police experts, they claimed to be able to use their practical view in a successful attempt to decode flexibly, yet in a standardized way, the order of prostitution ${ }^{13}$.

From the perspective of police experts, only their experience and authority guaranteed an appropriate representation of prostitution. Moral reformers, on the other hand, lacking experience and the authority of a practical view, could only misread the observed social facts; or, at least, it was thus that police experts defended themselves against the accusations made by moral reformers, who blamed the police for their obvious failure to control and confine prostitution. Nevertheless, their defensive strategy was successful, partly because both the police and their critics based their narratives on the same evidence and the same methodological principles. In terms of experience and the amount of information gathered, police experts were clearly superior to social reformers. Nevertheless, social reformers such as Theodor Bade tried to support their arguments by pointing to their own «fieldwork». When Bade published a book on prostitution in 1858 , he depicted himself as a philanthropic ethnographer, « who enters this shadowy region which is populated by human shades with the heart of a philanthropist... ${ }^{14}$.

To access the hidden structure of the criminal underworld, of which prostitution was an important part, both moral superiority and expertise were necessary. A real understanding of this alien world seemed to be possible only if detectives and moral reformers descended into the dark caverns where criminals indulged their desires and engaged in debaucheries, particularly in «dingy dives », which, Avé-Lallemant, for one, understood as «cozy hideouts» where "with his cronies» the criminal could expect to fulfill «all his lusts, as if atop a vermin-infested haystack ${ }^{15}$. This personal exposure to the pernicious reality of the criminal underworld can be seen both as a ritual of the visiting bourgeois, who, as Judith Walkowitz ${ }^{16}$ has observed, thus proved to himself his moral superiority, and as an ethnographic study. Moral superiority could be claimed by moral reformers and police experts alike. A wellprepared fieldtrip into the underworld, however, had to be supported by institutionalized knowledge and experience. Therefore, in an internal reply to

\footnotetext{
"Wennmohs (1823, p. 322).

12 Cf. Becker (1992, p. 284ff).

13 Cf. Becker (1994a, p. 160ff).

14 Bade (1858, p. 3).

15. Avé-Lallemant (1858, 2, p. 8 and 333).

16 Walkowitz (1980, p. 33ff).
} 
Bade's accusations, the head of the vice squad argued that «prostitution is a field that reveals itself comprehensively only very rarely to a layman $»$.

Police experts presented their «ethnographic » descriptions of prostitution as the results of impartial and objective observations. This is exactly the way in which Wilhelm Stieber, head of the Berlin detective squad and later head of Bismarck's secret service, understood his own study of prostitution in Berlin. Breaking with the past, he argued, modern social and criminological research tried to see even the most wicked person as another human being, whose life and deeds were to be studied carefully. The driving force, he claimed, was an intellectual curiosity that drew researchers into the deepest caverns of society ${ }^{18}$.

As police experts, they did not just follow their intellectual curiosity. Their entire lives and work had to be devoted to the common good, which seemed to be threatened by prostitution. This gave their intellectual curiosity an aura of practical interest. Reading further in Stieber's methodological self-description, we find this notion expressed clearly. He understands his own book as an attempt to reconnoiter the terrain on which the struggle between the police and the members of the criminal underworld would eventually take place ${ }^{19}$.

The practical view of police experts on prostitutes and their trade embodied not only their professional but also their gendered attitudes. They ordered the worlds of vice and respectability around male dominance and male necessities. Prostitution was seen not so much from the perspective of female supply, but rather from the viewpoint of male demand, which was closely linked to the particularities of the bourgeois family and the growing number of bachelors in bigger cities ${ }^{20}$. Men were believed to have an almost irresistible sexual drive - even more accentuated within the criminal class - which had to be relieved through sexual intercourse. A number of memoranda, reports, and publications by police officials and medical experts used this argument to defend the existing practice of tolerated, controlled prostitution. For some authors, the very fact that women had to cater to the sexual needs of men was part of the almost universal gender roles. Julien Jeannel, whose book on prostitutes was translated into German in 1869, quoted from the Bible to support this argument: Etenim non es creatus vir propter muliem, sed mulier propter virum ${ }^{21}$.

The concept of a universal male sexual desire and its influence on the need for prostitutes can be found early on and was applied in a differentiated way by introducing the concept of class-specific needs. A student of Joseph von Sonnenfels, one of late-eighteenth-century Europe's most prominent bureaucrats, who taught political economy at the University of Vienna, provides an interesting example of the reasoning at the end of that century. He wrote an anonymous pamphlet in which he argued against his teacher's defense of the ban on brothels in Vienna. He based his argument on the idea of a universal sexual drive in men, which he expressed with the Latin phrase malum necessarium. He saw, however, class-specific differences in the appeasement of this desire: members of the upper classes would have had

17 BLHA 16927: Polizeidirektor Hofrichter an den Polizeipräsidenten, 30.9.1857.

18 Stieber (1846, p. 1ff).

19 Stieber $(1846$, p. 2$)$.

20 Cf. Corbin (1982, p. 287ff).

21 I. Cor. XI. 9, quoted from Jeannel (1869, p. 77). 
numerous opportunities to satisfy their drives by exploiting the service of goodlooking servants, while unmarried men from the lower classes and from the military would have had to turn elsewhere ${ }^{22}$.

This line of argument can be found in most of the accounts written by police experts. Another version of class-specific needs for prostitution painted a more positive, moral picture of men. In a rescript dated November 30,1837, the Ministry of the Interior turned down the application of a private person who wanted to open a brothel for the upper classes in a provincial town in Prussia. The Ministry argued that members of the upper classes had to live exemplary lives. Only men from the lower classes could be allowed to resort to prostitutes. Their immorality would have been tolerated as a result of their lack of Bildung - of education and cultivation -, whereas men from the upper classes received sufficient education and training to control their natural instincts ${ }^{23}$. This idealistic notion of men, with its strong belief in the benefits of intellectual and moral education, failed, however, to transform the way in which police experts couched their concerns and conducted their administrative routines. It even stood in contrast to the objectives of the police. The police were charged with watching over citizens to prevent their falling prey to sinners or to their own sins; perfectly educated and reformed people would eventually render the institution superfluous.

\section{STRONG DRIVES - WEAK REASON: CLIENT AND «WHORE»}

Until the closing decades of the nineteenth century, the descriptions of the prostitute's personality depict her as a victim of her own sinful inclinations. As pointed out above, prostitutes were believed to represent the female type of dissoluteness ${ }^{24}$, the male counterpart of which would have been the Gauner - the most prominent type of a professional criminal until the late nineteenth century. In these writings, social causes, such as bad economic conditions and lack of work for laborers, were seen as promoting a career as a Gauner or as a prostitute only for those individuals whose personality did not allow a respectable response to hardship. Only women who were fond of fashionable clothes, idle, alcoholics, wicked, licentious, or nymphomaniacs, were expected to respond to economic hardship or to a reduction of their standard of living by prostituting themselves. Most police experts writing on prostitution believed that this configuration economic depravation and the existence of specific dispositions - could account for

22 Anonymous (1786, p. 5ff).

23 Rescript of the Ministery of the Interior and Police of 30.11 .1837 to the Head of Police in N.N., regarding the toleration of brothels. In: Kamptz'sche Annalen 21, 1837, p. 159-162, 162. The ministry applied the legal principles of the Allgemeines Landrecht (1794, p. 999ff) which put local police authorities in charge of supervising brothels. After someone asked for permission to open a new brothel, the local police authorities also decided whether or not the demand for it existed in their jurisdiction. Their decisions could be revoked by the superior authorities, which actually happened in the rescript of November 30,1837 . The ministery legitimized its repeal by pointing to the local police authority's mistaken assessment of the need for brothels. 
the existence of prostitution only when it also included the lack of intellectual and moral education, which they held responsible for the failure to develop reason and morality so as to restrain sensual inclinations ${ }^{25}$.

Prostitution was therefore understood mainly as a problem of strong physical inclinations and the lack of moral and intellectual qualities. Successful reintegration into bourgeois society was therefore complicated, since prostitutes and criminals developed habits that were attuned to the social dynamics of the criminal underworld and hence not compatible with bourgeois life. Reform institutions, such as penitentiaries, workhouses, and homes for fallen women, tried to influence the «wicked minds» of these social outcasts in two ways. Moral education was supposed to help them to understand the wickedness of their previous way of living. Practical training, especially forced labor (even on a treadmill), was believed to establish habits of work and diligence in both mind and body. This optimistic belief in the possibility of reforming habits through the practice of new routines was common at the end of the eighteenth and at the beginning of the nineteenth century. Immanuel Kant used the notion to argue that even dispositions could be acquired: If someone feigned respectability and friendliness over a long enough time, these characteristics would become part of his character ${ }^{26}$.

Reform was not possible in the case of every prostitute and criminal, however. Prostitutes were seen as being on a descending spiral from dissolute women to the occasional "pick-up» on the street to ending up finally in brothels. Police experts underlined the desperate situation of prostitutes in brothels, where they were exploited and deprived of their freedom. Even worse, as Stieber pointed out, was the fact that prostitutes in brothels relinquished the possibility of selecting their sexual partners and determining the number of sexual contacts they had. In his words, they gave every man a legal right to their bodies. They therefore fell to the lowest levels of society and morality. Stieber described them as a «bizarre monstrosity of our moral conditions.... ${ }^{27}$. It is highly characteristic of the contradictory character of the detectives' stereotypes of prostitutes that Stieber could give those women high marks as housewives and mothers in the unlikely event that they finally left the brothel and married ${ }^{28}$.

Police experts were certainly interested in the personalities and biographies of prostitutes. But their main concern was the role they played in the larger society. This role was seen in ambivalent terms. They welcomed the service that prostitutes rendered to the respectable male community, even if this required their more or less thorough segregation from the rest of society, especially in order to protect juveniles from harmful contact with them. At the same time, police experts were disturbed by the consequences of this social segregation. Prostitutes joined criminals as part of the vicious and dangerous criminal underworld. This underworld was believed to consist of men and women who had chosen a life apart from respectable citizens. Within the polarized view that police experts held of society, this criminal underworld was depicted as the negative image of bourgeois society ${ }^{29}$.

\footnotetext{
25 Cf. Stieber (1846, p. 83ff).

26 Kant (1798, p. 442).

27 Stieber (1846, p. 83).

28 Stieber $(1846$, p. 91$)$.

29 Cf. Becker (1994b, p. 150ff).
} 
Police experts ascribed prostitutes a fairly privileged position within this underworld, since they were the only ones allowed to surface in respectable society. Professional criminals, the Gauner, were assigned a different role. Criminals were assumed to have an intimate, yet disrupted relationship with bourgeois society, out of which they originally came and which they exploited through their insidious profession. Crime experts were convinced that, in stepping from bourgeois society into the criminal world, the Gauner had undergone a profound change of identity. There had to exist an essential difference between a member of the bourgeoisie and the Gauner. The Gauner personified falseness, while the citizen represented authenticity. Since he surfaced in a variety of masks, a Gauner was very difficult to apprehend ${ }^{30}$.

The prostitute, in contrast, was visible not only to juveniles, which caused severe problems, but also to detectives. This coincidence of their visibility and belonging to the criminal underworld made them the detectives' preferred source for information regarding the whereabouts of criminals and their «earnings». It was widely held that most of a criminal's booty ended up in the hands of prostitutes and pimps, and that these criminals found a very convenient hiding place in brothels, where they were not required to register and where they could satisfy their putative enormous sexual drives ${ }^{31}$. Accordingly, prostitutes and brothel owners were one of the main targets of police detectives when they were struggling to solve a crime. The cooperation of these individuals was traded for the police's tolerant attitude toward their business.

The cooperation of prostitutes and pimps with law-enforcement agencies was due in part to the highly complex nature of the regulations concerning prostitution ${ }^{32}$. These regulations attempted to ban prostitutes from numerous public places, theaters, and amusement facilities and were enforced to such an extent that prostitutes could get into trouble even on their way to their compulsory medical check-up. In short, the regulations were almost impossible to adhere to. The members of the vice squad were, however, flexible in their enforcement. A certain amount of violation was more likely to be accepted in the cases of more cooperative prostitutes. Prostitution as a tolerated but controlled trade was therefore an instrumental part of the prosecution of criminals both in Germany and in France ${ }^{33}$. From the perspective of police experts, the prostitute's - albeit forced - betrayal of boyfriends and clients associated her again with the criminal underworld, which was seen as being characterized by forgery and betrayal.

The visibility of prostitutes not only gave detectives access to the criminal underworld, it also gave the criminal underworld access to respectable families. Bodily and socially, prostitutes bridged the gap between the worlds of vice and respectability. This made them exceptionally dangerous, even more dangerous than members of the proletariat or criminals, as Stieber pointed out: «The proletarians and criminals socialize in closed social circles and societies that do not have frequent contact with the wealthier parts of society. The proletarian lives, suffers, starves, and freezes by himself; only for getting work or for begging does he

\footnotetext{
30 Cf. Becker (1994a, p. 158ff).

31 Cf. Becker (1804, p. 17) and Stieber (1860, p. 184).

32 Cf. Schulte $(1979$, p. 176ff).

33 Cf. Zimmermann (1847, p. 204) and Berlière (1992, p. 102ff) about the French case.
} 
approach his richer fellow citizens, and he tries to be useful rather than harmful. The criminal vegetates usually in partly [smart] and partly shy seclusion. He harms us with his crimes, but this nuisance is always only temporary and only very rarely affects an individual ». Prostitutes, however, threatened to penetrate all levels of bourgeois society; they made men from the upper classes dependent on their unbridled sexual lust and they corrupted juvenile males ${ }^{34}$.

The imminent danger that prostitutes posed to the moral integrity of young men could be tolerated only because of the quasi natural law of male sexual urges that had to be discharged somewhere. The police paid a high price for its tolerant attitude toward prostitution: Moral reformers repeatedly pointed to the intolerable situation in which the city's youth was placed. Exposed as innocent youngsters to the seductive influences of «vicious » women whom they met at one of the many dancing venues, they became increasingly entrapped in an immoral lifestyle. Merker, whom we met previously, saw the prostitute's corrupting influence on young males as the most immediate problem. He argued that «once young men develop an inclination for intercourse with prostitutes, they cannot willingly pull themselves away again». In his view, these young men often turned to embezzlement, forgery, and thievery to acquire the means that were necessary to meet the expectations of prostitutes. Since Merker held it almost impossible to cure these young men of their insidious inclination by imprisonment, he demanded that prostitutes be banned from city streets ${ }^{35}$.

Moral reformers and police experts alike were obsessed with the protection of youth from pernicious influences, such as contact with prostitutes, indecent speech, or lascivious books and plays. The police were given the assignment of enforcing moral hygiene. There was, however, no consensus about the most appropriate means to implement the regulations. Besides a variety of strategies for keeping books and plays with indecent contents out of the reach of juveniles, the crucial question was the approach to prostitution. Should prostitution be forbidden or should prostitutes simply be banned from the streets where their very appearance could corrupt the innocent? This question was difficult to answer for police experts in Germanspeaking countries. In the long run, as moral standards within all classes of society improved, they expected prostitution to become useless and meaningless. Merker was one of the few authors who believed firmly in the already existing moral superiority of German men and therefore embarked on a systematic critique of the French system, as it was presented by Parent-Duchatelet. Merker even questioned the need for prostitutes in places with a strong military presence, citing his own experience in the city of Erfurt as proof ${ }^{36}$.

Most of the German police experts, however, believed in the benefits of the French system and postponed the advent of moral superiority to later times. Therefore, they accepted and defended the existing systems of regulation, which were modeled on the French example. These regulations were institutionalized in various forms. During the first half of the century, brothels were quite common in German cities, even though the pressure from citizens' organizations and churches against these «domiciles of vicious activities » were mounting. They tried to force

\footnotetext{
34 Stieber (1846, p. 80ff).

35 Merker (1839, p. 37); cf. also Fröhlich (1851, p. 77).

36 Merker (1839, p. 69ff).
} 
the police to remove brothels and/or independent prostitutes from their neighborhood. Partly due to this mounting pressure, brothels were forbidden in Prussia during the second half of the century. Because of a clause in the penal code which penalized procuring, this strategy was finally extended to the rest of the German empire, even though several cities clung to their traditional system of licensed brothels and/or concentration of prostitutes in one single area. By closing down brothels in all of Germany and also in other parts of Europe, the police were merely responding to a change in the demand for venal sex. A growing number of bachelors looked for the excitement of flirtations and seductions in bars and dance-halls in addition to the spectacle of women who tried to attract men on the streets ${ }^{37}$.

Because this new structure in the supply of venal sex resulted in a higher visibility of prostitutes, police experts and moral reformers became alarmed. Self-styled moral reformers, teachers, and other respectable citizens secretly frequented notorious bars and dance-halls to watch what they saw as the steady descent of working-class youngsters into a wicked lifestyle and the corruption of adolescents from a bourgeois background. The latter was blamed especially on the presence of prostitutes at places where bourgeois people went for entertainment $t^{38}$. Less than a month after one of these reformers submitted an anonymous report, the Ministry of the Interior issued a rescript to the head of the Berlin police department, urging him to put an end to the «vicious» activities described in the report. Police detectives responded by deriding the exclusively moral approach of the philanthropic authors of the report, which had distorted the visiting bourgeois' perception of social realities. However, given that moral imperatives were also at the core of the police's work, police detectives found it difficult to discount the concerns raised in the report.

The activities and arguments of moral reformers were driven by the same sociopolitical agenda as those of the police. Both moral reformers and police experts employed the image of the criminal personality as a "fallen angel» in order to represent the imminent danger facing respectable, young men. In their narratives, every man had the potential to become a perfect human being, an angel; no one exhibited a personality at the time of his birth that one day might lead him astray. Certainly the authors were aware that only careful moral and intellectual education would bring forth all the best dispositions. For children of the lower classes, a minimum of Christian education was deemed sufficient to develop social habits that were appropriate for a respectable life in bourgeois society. Missing or misdirected education was held to be the breeding ground for sensual drives against which no moral and intellectual constraints could be deployed. Criminalists were far from believing that wrong education and strong sensual drives sufficed to start a criminal career. In their view, most criminals needed an additional impulse. During the first half of the nineteenth century, criminological writers looked at the biographies of criminals in an attempt to discover the crucial steps that led «fallen angels » away from a respectable life. Alcohol, regular encounters with prostitutes, avarice, and bad company were all found to be prominent factors ${ }^{39}$, albeit not the direct cause of

37 Cf. Corbin (1982, p. 301ff); Krafft (1996, p. 37ff).

38 Cf. Excerpt from a teacher's anonymous report to the board of the Evangelische Verein für kirchliche Zustände, 21.1.1851, in: BLHA, Pr. Br. Rep. 30, Berlin C: Polizei Präsidium, Tit. 121, No. 22: Acte betreffend das unsittliche Treiben halberwachsener Knaben und Mächen in öffentlichen Lokalen von Berlin, 1851, 16926; Bade (1858, p. 17ff). 
crime. Such influences first of all caused the person to deviate from a virtuous life, and it was this deviation that finally led to vice and misery.

Prominent among these influences was contact with prostitutes. Every criminal's biography shows that, as Rudolf Fröhlich phrased it, a calamitous relationship with a « vicious » woman initiated the criminal career ${ }^{40}$. Within this frame of thought, not every client of prostitutes succumbed to this vicious influence, however. Those who were believed to be particularly endangered, were immature persons whom police experts and moral reformers denied the ability to the use of sexual services provided by prostitutes and other women of the same kind as a simple commodity. Because such young men lacked intellectual sophistication, moral resolve, and had yet to develop and embody the habits of respectable citizens, detectives and moral reformers anxiously watched over any contacts they might have with indecency, above all with the apparently free and unrestricted lifestyle of prostitutes and criminals, which could easily drag them down into the criminal underworld. These concerns motivated many reformers and city officials to write letters to police departments demanding a stricter enforcement of the exclusion of apprentices and young students from brothels. At the same time, they called for a complete ban on indecent literature and images ${ }^{41}$.

Some of the criminological authors, such as Rudolf Fröhlich, saw the seduction and corruption of young bourgeois men as some kind of intentional revenge by prostitutes, as female members of the working class, for their prior seduction by men of a higher social standing. This gendered fear was even more prevalent with regard to the infection of men with syphilis. It was a widely held opinion that women who were infected with venereal disease took vengeance for this on the male sex by spreading the disease $\mathrm{e}^{42}$. In their reflections on the very beginnings of a prostitute's career, criminalists frequently blamed a failed love affair resulting in pregnancy or even in venereal disease. As a prostitute, she purged herself of emotional attachment to her clients, specialized in sex, and was therefore able to spread moral as well as physical contagion. This lack of attachment gave her a real dominance over immature men, who were now seduced by her. Her seductive abilities reversed the gender roles - which was also understood in terms of vengeance.

Police experts were not just concerned with the sons of respectable citizens being dragged into the criminal underworld when they pondered the problem of prostitution. They were also worried about the spread of venereal disease, which was understood in similar terms to the spread of moral contagion. In both instances, police and sanitary experts hoped to stop the further spread of the disease by isolating the persons already afflicted. Prostitutes were compelled to undergo medical examinations on a regular basis in order to reduce the risk of infection for male clients. This measure, which became part of the criminal code in Prussia ${ }^{43}$, covered only registered prostitutes. As a result, the members of the vice squad had two different tasks. First, they had to enforce these regulations on registered

\footnotetext{
40 Fröhlich (1851, p. 77).

41 Cf. Supplication of the Mayor of Berlin to the police headquarters of December 1, 1820, in which the case of a sixteen year old apprentice, who was infected with venereal disease in a brothel, was used as a reason to ask for a more thorough enforcement of existing regulations. BLHA Pr. Br. Rep. 30, Berlin C: Polizei-Präsidium, Tit 23, Nr. 1: Acte Generalie regarding brothels, 720, f. 102.

42 Cf. Quétel (1992, p. 124ff and 238).

43 Cf. Allgemeines Landrecht (1794, Th. II, Tit. 20, § 1002).
} 
prostitutes. Second, they were constantly on the look-out for hidden prostitutes, who lived on their own, evaded medical examinations, and avoided the stigma of being registered. Police experts understood this second class of prostitutes as extremely dangerous not only for the spread of venereal disease but also for disseminating a moral contagion. Clandestine prostitutes did not follow the rules which kept them out of the reach of immature persons and could therefore even more easily pull innocent men into a vicious lifestyle.

This police concern for unregistered prostitution prompted members of the vice squad to apprehend all unlicensed women who seemed to solicit men in the streets. The absence of sufficient indications that unmistakably signified a loose woman resulted in several public scandals when respectable women were arrested for prostitution. The detectives excused their mistakes by pointing to the blurred distinctions between respectable and « vicious " women: "With the current fashion of painting one's face and dressing up, one needs a very well-trained eye to tell prostitutes from respectable women ${ }^{44}$. The concern with the higher risk that uncontrolled prostitution posed to society also blocked the path of those prostitutes who wanted to quit. Police officials were expected to give these women all the help they needed. This supportive attitude was, however, neutralized by the need for control. How could one discriminate between genuine and feigned desires on the part of prostitutes to leave their trade? Considering the weak moral and intellectual condition of these women, only their future behavior would prove conclusive. To be on the safe side, members of the vice squad watched over these women's first steps in respectable trades. But this surveillance exposed their previous life to managers and their new colleagues, and often resulted in loss of their employment.

Even bureaucratic routines placed hurdles in the path of these women. The most serious consequences of this development emerged toward the end of the century when the communication network and a tight system of registration allowed the police and employers permanent access to a person's prior history. These difficulties are well documented in the letter of Elsbeth von Pigage, a former Lübeck prostitute, who sought regular employment in Hamburg. She wrote to the Lübeck police department, asking them to send her a certificate of registration, one that omitted her status as prostitute. Otherwise, she claimed, it would be impossible for her to break with the past ${ }^{45}$. In dealing with repentant prostitutes, the police were torn between suspicion, as an element in its preventative approach, and moral reform, which was not easy to ascertain by bureaucratic procedures. Moreover, police detectives were interested in maintaining the status quo as it gave them access to information about the criminal underworld. Altogether, these forces contributed to make the vice squad into a «machine for turning temporary prostitutes into permanent ones», as Alain Corbin convincingly argues ${ }^{46}$.

The violation of the rights of prostitutes to decide about their lives stood in sharp contrast to the intrinsic objectives of the police. This contradiction was recognized by police experts, who nevertheless supported the work of the vice squad. To them,

44 Report of a detective from 11.5.1884, Pr.Br.Rep. 30, Berlin C: Polizei Präsidium, Tit. 121, No. 26. Acta betreffend die hiesigen sittlichen Zustände, 1857-1898, 62r.

4s Letter of Elsbeth von Pigage to Lübeck police department, February 18, 1913. Archiv der Hansestadt Lübeck, 739.

46 Corbin $(1982$, p. 335). 
the vice squad was necessary in order to combat the threat that prostitutes posed to the moral and physical constitution of the social body. In their reflections on this threat, they understood venereal diseases not within the framework of a steady, physical decline of the social body but rather within an economic frame of thought. Even though medical concerns were prominent in the writings of police and public health experts throughout the century, the meaning of the venereal peril shifted remarkably toward the end of the century. Until then, toleration and surveillance of prostitution were justified by the need to contain the spread of venereal disease, seen in terms of an economic problem. Men infected with this disease were unable to comply with the demands of either bourgeois society or the military ${ }^{47}$. The same men spread syphilis, as they inflicted the harm of venereal disease even on innocent people, such as their wife, fiancée, or their newborn children. But whereas venereal disease was a primary concern, it was not an immediate threat to society's wellbeing. In order to establish a link between individual, physical decay and the decline of German society, the authors of criminological studies needed a different conceptual framework.

The only framework that linked the social problem of prostitution to an analysis of society as a whole was the metaphor of the social body. Just as the human body can bear some physical shortcomings, the social body was able to tolerate some social pathologies without collapsing, Merker argued ${ }^{48}$. As soon as social problems, such as prostitution, appeared to be gaining ground, it became necessary for police experts to relieve the social body of its disease by means of an appropriate cure. Within this framework, the social disease of prostitution served as a referent for a variety of social problems: the loss of able-bodied men for military service, the loss of well-educated men for bourgeois trades and professions, the upsurge in crimes against property, and finally the increasing number of young citizens who took to crime. The most unsettling evidence that criminological writers gained from their analysis of prostitution did not refer to the weakened bodies of men suffering from venereal disease, however. The real problem, as they saw it, were the strong sexual urges in men's bodies which dominated moral and intellectual constraints and could be aroused easily by pernicious influences.

\section{WEAK BODIES: PROSTITUTES}

In the last two decades of the nineteenth century, there was a remarkable shift in the discourse on crime and criminals, which altered fundamentally the ways in which criminals and prostitutes were viewed and represented. Part of this transformation of the narrative on criminals was a relocation of the site of this discourse from the legal to the medical-anthropological professions. This medicalisation of social problems was the result of a variety of changes taking place in German society, which contributed to an increase in authority for the members of the medical profession.

From the end of the nineteenth and continuing into the early twentieth century, books and articles which provided new theories and insights into the lives, habits,

47 Cf. Merker (1839, p. 58ff).

48 Merker (1839, p. 3ff). 
and bodies of criminals were written by psychiatrists, medical experts, and anthropologists. They used ethnographic descriptions of criminal lifestyles, written by police experts and magistrates of previous generations, in order to construct the social and cultural contexts of criminals. Authors with a practical experience in crime fighting and prevention ceased to play a role in providing criminological insights. They found themselves now on the receiving end of the discourse and incorporated the new criminological ideas into their drive to reform the penal code, to develop new tools for preventing criminality, and to tailor the existing penitentiaries to meet the new theories about the very nature of criminals.

The medicalisation of criminological reasoning began, however, long before the end of the century. It dates back at least to the late eighteenth century, when enlightened psychiatrists pondered the criminal liability of offenders who showed signs of insanity. A second tradition can be linked to the efforts of public hygiene experts, such as Parent-Duchâtelet, who studied prostitution with the same incentive and verve that he devoted to the study of the sewer system. Hygiene experts became involved in the discussion of criminality and prostitution through the issue of venereal disease and the control of the spread of contagious diseases. They had always looked at the bodies and minds of criminals in different ways from legal experts. But it was only at the end of the nineteenth century, that this medical approach became the dominant one. One of the most distinctive features of this approach was its focus on individual bodies and minds. Whereas police experts used the bodies of criminals and prostitutes in their (re-)construction of the criminal underworld to highlight their wicked nature, medical writers used the habits and moral characteristics of criminals to support their theories, which were based on the punctilious analysis of individual bodies and minds.

Even though the works of the members of the positivist school were sprinkled with tables and statistics, late nineteenth-century criminologists nevertheless despised the tyranny of statistical evidence as much as did the police experts in their ethnographic description of the criminal underworld. Both trusted only the interpretative skills of experienced men. As Cesare Lombroso, the founding father of criminal anthropology, wrote: «Large numbers are useful if we are dealing with evidence that everyone can record. If we do not record only age, sex, and occupation, but rather the psychological characteristics or the shape of the skull of a group of criminals, we cannot arrive at large numbers even after long lives. With respect to these delicate evidences, which require special aptitude and training to record, the large numbers of the official statistics, which are collected by uneducated clerks, are of much less value than a few observations collected by competent men ${ }^{49}$. Lombroso's argument shows that anthropologists and medical experts, who were engaged in criminological research at the turn the century, also claimed to have a trained and educated eye which allowed them to integrate a wide body of cultural knowledge into their scrutiny of criminal bodies, minds, and lives.

While the legal and police experts framed their empirical observations within the master narrative of the fallen angel, anthropologists and medical experts looked at criminality within a medical-evolutionary framework. Unlike fallen angels, the criminals/prostitutes of the late nineteenth century seemed to have no real choice. They were understood as embodying determining forces that sprang from their

49 Lombroso (1887, p. XIX). 
social and biological environment. Along with gender roles that were given the status of natural laws, these influences drove men and women into their respective careers.

Erich Wulffen, a high-ranking official in the Ministry of the Interior in Saxony, used these narratives to explain the existence of prostitution in modern Germany along with male exploitation of the female sex and the female's need for protection, which he understood as an integral part of gender hierarchy and as an outcome of the evolution of mankind: "In spite of their sexual passivity, women, especially young and poor ones, can be seduced easily. The man is always economically and socially superior; the woman succumbs to any kind of suggestion, as can be proven with the follies of fashion, which also originate with men! Ethical restraints are not strong in women, they are easily overcome; women's intellectual development lags behind, their logical thinking is deficient, their emotional life easily overwhelms their stream of consciousness. Therefore, a woman unprotected by family and education is prone to become a prostitute. Moreover, in every woman the whorish nature is physiologically and psychologically dormant. This is the result of her anthropological evolution. Using women's biological tendencies, men have bred this whorish nature $"^{50}$.

Wulffen's detour through the history of mankind reminds us of Lombroso's lengthy accounts of the reappearance of atavistic morphological and psychological traits in modern society. At the core of this doctrine lay the idea that ontogeny recapitulated phylogeny, that is, that every human had to experience the complete evolution of living beings ${ }^{51}$. From this viewpoint, morphological or psychological development arrested at a certain stage prompted the appearance of atavistic characteristics. Even though most German and French criminological writers questioned Lombroso's theory of atavism, authors such as Wulffen obviously built their arguments on Lombroso's powerful images. This can be seen from a comparison of Wulffen's account with Lombroso's ideas about the very origin of prostitution. Lombroso used the same image of polygamous sexuality as characteristic of primitive women: «The primitive woman was rarely a murderess; but she was always a prostitute, and remained such until semi-civilized epochs ${ }^{52}$. Whereas the technicalities about the transfer of this original female designation from the primitive stages of mankind to modern Europe remained contested, the notion of women's inferior ethical, moral, and intellectual standards allowed men to fend off increasing demands for political participation and to conceal the sexual exploitation of woman behind the screen of natural law.

These prostitutes and criminals were no fallen angels. Rather they had been prevented from finishing their psychological and physical formation. This was at least the way criminologists at the turn of the century told the story ${ }^{53}$. When they were exploring the «real» causes of «antisocial behavior», they were talking about impaired (wo)men. The main characteristic of these victims of degenerating influ-

so Wulffen (1921, p. 678).

5) Baer (1893, p. 338), Haeckel (1906, p. 168ff) and Lombroso (1887, 1, p. 97ff); cf. also Becker (1995), Gould (1977, p. 120ff), Gould (1988, p. 118ff), Richards (1992, p. 17ff), Strasser (1984, p. $63 \mathrm{ff})$.

52 Lombroso, Ferrero (1895, p. 111).

53 Cf. Corbin (1982, p. 441). 
ences was their weakness, which prevented their successful integration into bourgeois life. Tramps were the male prototype, prostitutes the female equivalent of this paradigm of weakness. This master narrative guided different interpretations of prostitution as a social problem. A prostitute's weakness - one that encompassed her body, her will-power, and her mind - could be explained by hereditary influences, malnutrition, and improper hygiene, or all of these. The main point, however, was that this weakness gave them no freedom to choose their career. Gustav Aschaffenburg expressed this well in his influential book on criminality: «Just as the weak are the first to fall prey to devastating epidemics, the numerous psychopathic types will perish first - more slowly or quickly - in the morass that is termed prostitution ${ }^{54}$.

Degeneration - as a «medico-psychological discussion of heredity 》 - was not unknown to participants in the medical discourse of the early nineteenth century ${ }^{55}$. The degeneration theory of Benedict Morel, first published in 1857, can be seen nevertheless as a new approach. It was «an account of regressive tendencies in both individuals and modern sciences » (Harris) and provided, for the first time, a conclusive system linking somatic and psychological diseases to an underlying force of weakness and decay, which in turn was thought to spread at an increasing rate throughout society. This added a genealogical dimension to the study of crime and deviance. Case studies in well-known textbooks no longer focused exclusively on the biography of the suspects, but discussed their heritage, habits, and physical bodies at length. A typical example may be found in the first paragraph of Richard von Krafft-Ebing's Psychopathia Sexualis, where he describes a male pervert who abused women: "Mister X., aged twenty-five; father syphilitic, died of paretic dementia; mother hysterical and neurasthenic. He was a weak individual, constitutionally neuropathic, and presented several anatomical signs of degeneration... $\rangle^{56}$.

Within this paradigm of degeneration, prostitutes had two different roles: as victims and as agents of continual degeneration. The image of women too weak to protect themselves from their own «whorish» nature and from seduction by men had far-reaching consequences for police strategies. It guided legislation against and widespread police concerns with the issue of the so-called white slave trade. To prevent the development of large-scale trade in innocent young women and their «enslavement» in foreign brothels, the first international cooperation between police forces was established at a conference held in Paris in 1902. The decisions to combat this pernicious trade with administrative measures were ratified in 1904, whereas the attempts to standardize legislative responses to this crime were stalled for a long time ${ }^{57}$. As a result of the administrative measures, every participating country created a central unit at one of its police headquarters to collect information on agents who specialized in this type of trade and to communicate directly with corresponding units of other countries. This was a major breakthrough in international police cooperation. Before that, communication with the police forces of

\footnotetext{
54 Aschaffenburg (1903, p. 78).

55 Cf. Harris (1991, p. 51).

S6 Krafft-Ebing ([1902] 1965, p. 69).

57 Cf. Corbin (1982, p. 431).
} 
different countries had to go through diplomatic channels and was, accordingly, slow ${ }^{58}$.

These efforts were rooted almost exclusively in a narrative of prostitution which saw female prostitutes as weak, as unable to take care of themselves, and as especially vulnerable when they tried to venture outside their social boundaries. The struggle against international procurers was not intended to improve the situation of the «real» victims, miserable prostitutes, who were sold from one procurer to the next, but rather to rescue innocent virgins who were sent abroad under some pretext in order to force them into prostitution. This second type of victim of an international white slave trade was, however, almost non existent. At least in Germany, there was no significant evidence confirming the existence of a largescale international trade in innocent women, as was pointed out by Robert Heindl, one of the leading police experts of Imperial Germany and the Weimar Republic. He was one of the few experts highly critical of the measures taken against the white slave trade. To support his criticisms, he emphasized that almost no one had ever been convicted of this crime. Moreover, he noted that only a very small number of individuals (only 29 before 1912) had ever been targeted by gossip or other forms of denunciation as having been involved in this kind of trade; their photographs had then been taken by the Berlin police department. To Heindl, the concern with white slave traffickers was exaggerated and due to a press campaign that was based mostly on imagination ${ }^{59}$.

The writings of Heindl were not the only ones to point out the lack of evidence for the existence of white slave traffic in the sense of commerce in women who were either virgins below the age of consent or unwilling to become prostitutes. Further hints can be found in an impressive number of rescripts from the Ministry of the Interior in Berlin and in the responses from provincial police forces. The most telling one dates from March 24, 1900. The Ministry of the Interior refers to a rescript from September 1899, in which regional police headquarters were asked to provide the ministry with information regarding the activities of white slave traffickers within their jurisdiction. After the Ministry received only negative responses, it replied: «There can be no doubt that this kind of international trade exists, however, the agents have been successful in evading legal prosecution. It has therefore to be the task of all agencies to pursue this problem with eagerness and attention and to shadow carefully all suspicious persons and observe public houses ${ }^{60}$. These remarks show once more that the white slave trade has to be considered to be a subject « in which it is difficult to disentangle myth from reality », as Alain Corbin observed with regard to France ${ }^{61}$. This myth built on an image of

58 This international police cooperation can be understood as the continuation of similar cooperative efforts between the German States since the 1830 s. These earlier attempts to provide police departments with the opportunity of direct communication with their peers from neighboring states were thought to further the combat against politically defined enemies of the common good. (Siemann 1985, p. 87ff). Nevertheless, these networks and some other initiatives were already used for the purposes of detective work.

Heindl (1926, p. 303ff).

so Rescript of the ministery of the Interior to the Oberpräsident of the province of Hanover, March 24, 1900. HStA Hannover, Hann 122a, Oberpräsidium Hannover, 2654: Acta generalia betreffend die Bekämpfung der Unisttlichkeit. Internationaler Mädchenhandel für unzüchtige Zwecke. Einrichtung von Bordellen. 1891-1942.

Corbin (1982, p. 405). 
women as the weaker sex, who had to be placed under the guardianship of families or state agencies, which was all the more compelling in times of rising demands for equal rights for women.

If we look at other countries, a somewhat different picture emerges. Russia and the Austro-Hungarian monarchy were much more affected by the white slave trade, since Eastern European women were sent to brothels all around the world, especially to the Near East, to South-America, and to the United States, even though there was a declining demand in North America. Vienna, Budapest, Odessa, Genova, Trieste, and Naples as well as Marseilles, Bordeaux, Le Havre and Southampton were the main continental markets and places of embarkation. The eastern Mediterranean and Asian market was run by procurers in Alexandria, the South American market had its centers in Montevideo and Buenos Aires ${ }^{62}$. Police experts tried to unravel the structure of the market as well as the identities and strategies of the procurers. As early as 1885 , the police headquarters of Lemberg (Galicia) notified the police in Vienna of the existence of a lively white slave trade whose main protagonists were identified as Jews ${ }^{63}$. Even though surviving reports from consular agencies and police experts indicate fraudulent and deceptive strategies in the recruitment of prostitutes in some cases, there is strong evidence that most of the women who went to brothels and stayed there actually knew about the nature of the trade that they were expected to pursue. Therefore, we can at least agree with Heindl's second argument, namely, that the white slave trade frequently involved registered prostitutes who were traded between different procurers. Their fate was desperate enough, but they were not the center of attention of the crusade against white slave trade ${ }^{64}$.

The threat that prostitutes posed to society came from their role as agents who weakened the social body by transmitting venereal disease, especially when the disease was passed on to newborn babies. Syphilis was thought to have the potential to seriously affect a newborn's constitution. Although inherited syphilis had been discussed previously, within the narrative framework of degeneration and impaired (wo)men, it was endowed with new meaning. On the one hand, syphilis became one indication of an individual's degenerate constitution, which left him/her improperly equipped to face the harsh realities of bourgeois society ${ }^{65}$. On the other hand, criminologists identified syphilis and the excessive consumption of alcohol as principal agents of damage to the embryo: «Through several harmful influences of the paternal or maternal sex cells, the embryo can be damaged and such damage, which is unfortunately not a rare occurrence, results in the intellectual inferiority of the child ${ }^{66}$.

From the perspective of police experts, prostitutes were a prime source of venereal disease infections. Within the new framework of degeneration, their role continued to be that of connecting the world of bourgeois respectability and strength to the criminal underworld dominated by weakness and disease. Across the bridge of prostitution, the "pernicious germs » of venereal disease flowed into respectable

\footnotetext{
62 Cf. Corbin (1982, p. 419ff).

63 Cf. Oberhummer (1938, p. 78ff).

64 Heindl (1926, p. 304); cf. also Corbin (1982, p. 432ff).

65 Cf. Sommer (1904, p. 264ff).

${ }^{6}$ Cf. Lichem (1935, p. 585).
} 
families. Society had to be protected against this threat - or so the argument went just as weak women had to be protected against inappropriate exploitation.

Prostitutes were indeed a main source of infection because they had frequent intercourse with numerous sexual partners who had not necessarily been screened for their health condition. In order to prevent the further spread of venereal disease, prostitutes were forced to undergo regular medical examinations. This was a widely accepted means of checking the spread of degeneration. This spread was viewed as even more threatening because it had the potential to burden not only contemporary but also future society. Sterile women, insane offspring, and men without willpower represented the fears connected with the further diffusion of syphilis. Seen from the perspective of competing nation-states, a degenerating population seemed to jeopardize the very independence of states, nations, and races. The obsession of French and British social reformers with falling birth rates at the turn of the century is well known $n^{67}$. Similar concerns can also be found in the writings of German police and medical experts, even though the demographic situation in Germany provided a different basis for these reflections ${ }^{68}$.

With their narratives guided by the concept of degeneration, criminological writers claimed to have found a unique driving force behind every kind of antisocial behavior, from vagabondage to prostitution. They used these findings to justify widespread recourse to preventative and invasive measures ${ }^{69}$. The leading German penologist, Franz von Liszt, regarded repeat offenders to be the «general staff» of a group of people considered to be society's main enemy ${ }^{70}$. This group was composed of beggars, tramps, prostitutes, alcoholics, Gauner, and pimps. Von Liszt argued that these people embodied several social pathologies, which he labeled «proletariat $\gg^{71}$. The criminal personality, as intensifier of all social pathologies, was therefore seen as one of the chief menaces confronting the modern state. Their faith in the need for a broad range of preventative measures connected representatives of criminal law, welfare agencies, and the medical sciences ${ }^{72}$.

\section{CONCLUSION}

These two models of reasoning about prostitutes were not separated in the idealtypical way that I have described here. The two concerns of moral and physical contagion were present at any given time in the history of this discourse. Certain patterns of consumption and reproduction as well as the lack of a work spirit were in both cases at the core of concerns about deviance. If we look at the two models for representing deviance as stereotypes, in the sense of cognitive structures, we can easily delineate some differences: These two models featured almost identical peripheral attributes, ranging from idleness and excessive consumption of liquor to

\footnotetext{
67 Cf. Mitchell (1991, p. 97ff) and Soloway (1995, p. 38ff).

68 Cf. Wulffen (1921, p. 688ff).

69 Cf. Wetzell (1997).

70 Cf. Frommel (1991, p. 486); the difficulties in equating recidivism with criminal tendencies were already discussed from Sommer (1904, p. 348ff) and in the commentary of Kurella (1912, p. $51 \mathrm{ff})$.

71 Liszt (1905, p. 167).

72 Cf. Grünhut (1930, p. 3), Prins (1906, p. 82) and Harris (1991, p. 94).
} 
physiognomic characteristics. These attributes were given different meanings depending on the focal attributes and the master narratives into which they were embedded. The first stereotype featured deception as the most significant characteristic of criminals, whereas the second stereotype focused on weakness. The two focal attributes were closely linked to two different master narratives - fallen angel and impaired (wo)men - which in addition endowed the peripheral characteristics with their own meaning and provided a frame of thought which narrowed the choices for combating vice, deviance, and crime.

In the first half of the nineteenth century, when the fear of moral contagion was dominant, medical experts raised the issue of social hygiene and the need to guard against the spread of venereal disease. At this time, the arguments from medical experts were still framed by the fallen angel narrative. Innocent children and women could be infected and thus become victims. This victimization was by then seen only in terms of an insidious corruption of middle-class life and could make a difference with regard to the victims' morality when they themselves actually decided in favor of vice and deviance. Only the introduction of the concept of degeneration as a different narrative linked this medical concern with the ongoing depravation of society.

At the turn of the century, even moral contagion was warded off in these terms. Children and juveniles were seen as persons whose intellectual and moral facilities were not yet completely developed. Some of them - the natural born criminals were thought to be impaired from reaching a final state of development in any case. For the good of the rest of the population, there was an urgent need to keep stillmalleable minds away from pernicious influences. From the viewpoint of social reformers as well as medical and police experts, everyone who lagged behind in their development required additional protective measures. Their confinement, in workhouses and reformatories for example, did not aim to reform them morally, but rather to isolate them and shield them from their own atavistic drives as well as to protect society.

These two master narratives not only gave specific meaning to an empirical field that was not as distinct as the two different explanations of crime and prostitution would suggest, they were also crucial to defining links between representations of criminals and contemporary cultural knowledge. In doing so, they opened the possibilities of exchange between specialized criminological discourse on the one hand and literary, legal, philosophical, and theological reflections, on the other.

Peter Becker

European University Institute Department of History and Civilization

Via Bocaccio, 121

I-50133 Firenze

E-mail : pbecker@datacomm.iue.it

\section{REFERENCES}

Abel, J.F., Lebensgeschichte Friedrich Schwahns, in Sammlung merkwürdiger Rechtsfalle aus dem Gebiete des peinlichen Rechts, Nürnberg, 1794, p. 269 -354 (Reprint: Boehncke, 
H., Sarkowicz, H., (Eds.), Die deutschen Räuberbanden, vol. 1, Frankfurt/Main, Eichborn, 1991, p. 256-283).

Allgemeines Landrecht für die Preußischen Staaten von 1794, Reprint, Neuwied, Luchterhand, 1994.

Anonymus, Bordelle sind in Wien nothwendig. Herr Hofrath von Sonnenfels mag dagegen auf seinem Katheder predigen, was er will, 1786.

Aschaffenburg, G., Das Verbrechen und seine Bekämpfung. Kriminalpsychologie für Mediziner, Juristen und Soziologen, ein Beitrag zur Reform der Strafgesetzgebung, Heidelberg, Winter, 1903.

Ave-Lallemant, F.Ch.B., Das deutsche Gaunerthum in seiner social-politischen, literarischen und linguistischen Ausbildung zu seinern heutigen Bestande, Leipzig, Brockhaus, 1858.

Bade, Th., Uber Gelegenheitsmacherei und öffentliches Tanzvergnügen, Berlin, Friedländer'sche Buchhandlung, 1858.

Baer, A., Der Verbrecher in anthropologischer Beziehung, Leipzig. Thieme, 1893.

Becker, J.N., Actenmäßige Geschichte der Räuberbanden an den beyden Ufern des Rheins, vol. 2, Köln, Keil, 1804.

Becker, P., Randgruppen im Blickfeld der Polizei. Ein Versuch über die Perspektivität des «praktischen Blicks », Archiv für Sozialgeschichte, 1992, 32, p. 283-304.

Becker, P., Une sémiotique de l'escroquerie: le discours policier sur l'escroc au XIX $\mathrm{X}^{\mathrm{c}}$ siècle, Déviance et Société, 1994a, XVIII, 2, p. 155-170.

Becker, P., Kriminelle Identitäten im 19. Jahrhundert. Neue Entwicklungen in der historischen Kriminalitätsforschung, Historische Anthropologie, 1994b, 2, p. 142-157.

Becker, P., Der Verbrecher als «monstruoser Typus». Zur kriminologischen Semiotik der Jahrhundertwende, in Hagner, M., (Ed.), Der falsche Körper. Beiträge zu einer Geschichte der Monstrositäten, Göttingen, Wallstein, 1995, p. 147-173.

Berlière, J.M., La police des mours sous la III République, Paris, Seuil, 1992.

Bonß, W., Die Einübung des Tatsachenblicks. Zur Struktur und Veränderung empirischer Sozialforschung, Frankfurt/Main, Suhrkamp, 1982.

Corbin, A., Les filles de noce. Misère sexuelle et prostitution (XIX siècle), Paris, Flammarion, 1982.

Dainat, H., Wie wenig irgend ein Mensch für die Unsträflichkeit seiner nächsten Stunde sichere Bürgschaft leisten könne ! Kriminalgeschichten in der deutschen Spätaufklärung, in Schönert, J., (Ed.), Erzählte Kriminalität. Zur Typologie und Funktion von narrativen Darstellungen in Strafrechtspflege, Publizistik und Literatur zwischen 1770 und 1920, Tübingen, Niemeyer, 1991, p. 193-204.

Falkenberg, C., Versuch einer Darstellung der verschiedenen Classen von Räubem, Dieben und Diebeshehlem mit besonderer Hinsicht auf die vorzüglichsten Mittel sich ihrer zu bemächtigen, ihre Verbrechen $z u$ entdecken und $z u$ verhüten. Ein Handbuch für Polizeibeamte, Criminalisten und Gensd'armen, vol. 2, Berlin, Dunker \& Humblot, 1818.

Fröhlich, R., Die gefährlichen Klassen Wiens. Darstellung ihres Entstehens, ihrer Verbindungen, ihrer Taktik, ihrer Sitten und Gewohnheiten und ihrer Sprache. Mit belehrenden Winken über Gaunerkniffe und einem Wörterbuch der Gaunersprache, Wien, Wenedikt, 1851.

Frommel, M., Präventionsmodelle in der deutschen Strafzweck-Diskussion. Beziehungen zwischen Rechtsphilosophie, Dogmatik, Rechtspolitik und Erfahrungswissenschaften, Berlin, Dunker \& Humblot, 1987.

Frommel, M., Internationale Reformbewegung zwischen 1880 und 1920, in Schönert, J., (Ed.), Erzählte Kriminalität. Zur Typologie und Funktion von narrativen Darstellungen 
in Strafrechtspflege, Publizistik und Literatur zwischen 1770 und 1920, Tübingen, Niemeyer, 1991, p. 467-495.

Gould, S.J., Ontogeny and Phylogeny, Cambridge, Mass., Harvard University Press, 1977.

Gould, S.J., Der falsch vermessene Mensch, Frankfurt/Main, Suhrkamp, 1988.

Gray, R., Sign and Sein. The Physiognomikstreit and the Dispute over the Semiotic Constitution of Bourgeois Individuality, Deutsche Vierteljahresschrift für Literaturwissenschaft und Geistesgeschichte, 1992, 66, p. 300-332.

Grünhut, Die soziale Gerichtshilfe, Mitteilungen der Internationalen Kriminalistischen Vereinigung, 1930, NF 4, p. 3-26.

Haeckel, E., Prinzipien der generellen Morphologie der Organismen, Berlin, Reimer, 1906. Harris, R., Murders and Madness. Medicine, Law, and Society in the fin de siècle, Oxford, Clarendon Press, 1991.

Heindl, R., Der Berufsverbrecher. Ein Beitrag zur Strafrechtsreform, Berlin, Pan-Verlag, 1926.

Jeannel, J.F., Die Prostitution in den grossen Städten im neunzehnten Jahrhundert und die Vernichtung der venerischen Krankheiten, Erlangen, Enke, 1869.

Kant, I., Anthropologie in pragmatischer Hinsicht (1798), Frankfurt/Main, Suhrkamp, 1968.

Kant, I., Metaphysische Anfangsgründe der Rechtslehre. Metaphysik der Sitten. Erster Teil (1797), Hamburg, Meiner, 1986.

Krafft, S., Zucht und Unzucht. Prostitution und Sittenpolizei im München der Jahrhundertwende, München, Hugendubel, 1996.

Krafft-Ebing, R. von, Psychopathia Sexualis. With Especial Reference to the Antipathic Sexual Instinct. A Medico-Forensic Study [1902], New York, Stein and Day, 1965.

Kurella, H., Kriminal-Anthropologie und Strafrecht im Lichte der Verhandlungen des VII. Internationalen Kongresses für Kriminal-Anthropologie in Köln, 9.-13. Oktober 1911, in Kurella, H., Anthropologie und Strafrecht. Zwei Vorträge, Würzburg, Kabitzsch, 1912, p. 17-84.

Lichem, A., Die Kriminalpolizei. Handbuch für den kriminellen Polizeidienst, 2nd ed., Graz, Leykam, 1935.

Lichtenberg, G.Ch., Uber Physiognomik; wider die Physiognomen. Zur Beförderung der Menschenliebe und Menschenkenntnis (1778), Frankfurt/Main, Insel, 1986.

Lichtenberg, G.Ch., William Hogarth's Zeichnungen. Nach den Originalen in Stahl gestochen. Mit der vollständigen Erklärung derselben von G.C. Lichtenberg, $2^{\text {ad }}$ ed., Stuttgart, Rieger, 1857.

Liszt, F. von, Strafrechtliche Aufsätze und Vorträge, vol. 1, Berlin, Guttentag, 1905.

Lombroso, C., Der Verbrecher in anthropologischer, ärztlicher und juristischer Beziehung, vol. 1, Hamburg, Richter, 1887, vol. 2, Hamburg, Verlagsanstalt, 1890.

Lombroso, C., Ferrero, W., The Female Offender, London, Unwin, 1895.

Merker, J.F.K., Die Hauptquellen der Verbrechen gegen die Eigenthums-Sicherheit in Berlin mit Hindeutung auf die Möglichkeiten der Verminderung derselben, Berlin, Krause, 1839.

Mitchell, A., The Divided Path. The German Influence on Social Reform in France after 1870, Chapel Hill, University of North Carolina Press, 1991.

Morel, B.A., Traité des dégénérescences physiques, intellectuelles et morales de l'espèce humaine, Paris, Baillière, 1857.

Nye, R.A., Crime, Madness and Politics in Modern France. The Medical Concept of National Decline, Princeton, Princeton University Press, 1984. 
Oberhummer, H., Die Wiener Polizei. Neue Beiträge zur Geschichte des Sicherheitswesens in den Ländern der ehemaligen österreichisch-ungarischen Monarchie, Wien, Gerlach \& Wiedling, 1938.

Pick, D., Faces of Degeneration. A European Disorder, c. 1848-c. 1918, Cambridge, Cambridge University Press, 1993.

Prins, A., Die Gemeingefährlichen, Mitteilungen der Internationalen Kriminalistischen Vereinigung, 1906, 13, p. 81-84.

Quétel, C., History of Syphilis, Baltimore, The Johns Hopkins University Press, 1992.

Quetelet, A.L.J., Physique Social, ou: Essai sur le développement des facultés de l'homme, Paris, Baillière, 1869.

Reagin, N.R., A true woman can take care of herself: the debate over prostitution in Hanover, 1906, Central European History, 1991, 24, p. 347-380.

Richards, R.J., The Meaning of Evolution. The Morphological Construction and Ideological Reconstruction of Darwin's Theory, Chicago, University of Chicago Press, 1992.

Rochlitz, Ch., Das Wesen und Treiben der Gauner, Diebe und Betrüger Deutschlands, nebst Angabe von Maßregeln, sich gegen Raub, Diebstahl und Betrug zu schützen, und einem Wörterbuch der Diebessprache, Leipzig, Schmidt, 1846.

Schmidt, E., Einführung in die Geschichte der deutschen Strafrechtspflege, 3rd ed., Göttingen, Vandehoeck \& Ruprecht, 1965.

Schönert, J., Bilder vom «Verbrechermenschen» in den rechtskulturellen Diskursen um 1900: Zum Erzählen über Kriminalität und zum Status kriminologischen Wissens, in Schönert, J., (Ed.), Erzählte Kriminalität. Zur Typologie und Funktion von narrativen Darstellungen in Strafrechtspflege, Publizistik und Literatur zwischen 1770 und 1920, Tübingen, Niemeyer, 1991, p. 497-531.

Schulte, Ch., Radikal böse. Die Karriere des Bösen von Kant bis Nietzsche, München, Fink, 1988.

Schulte, R., Sperrbezirke. Tugendhaftigkeit und Prostitution in der bürgerlichen Welt, Frankfurt/Main, Syndikat, 1979.

Siemann, W., «Deutschlands Ruhe, Sicherheit und Ordnung». Die Anfänge der politischen Polizei 1806-1866, Tübingen, Niemeyer, 1985.

Soloway, R.A., Demography and Degeneration. Eugenics and the Declining Birthrate in Twentieth-Century Britain, Chapel Hill, University of North Carolina Press, 1995.

Sommer, R., Kriminalpsychologie und strafrechtliche Psychopathologie auf naturwissenschaftlicher Grundlage, Leipzig, Barth, 1904.

Stieber, W., Die Prostitution in Berlin und ihre Opfer. Nach amtlichen Quellen und Erfahrungen. In historischer, sittlicher, medizinischer und polizeilicher Beziehung beleuchtet, Berlin, Hoffmann \& Campe, 1846.

Stieber, W., Practisches Lehrbuch der Criminal-Polizei. Auf Grund langjähriger Erfahrungen zur amtlichen Benutzung für Justiz- und Polizeibeamte und zur Warnung und Belehrung für das Publikum bearbeitet, Berlin, Hayn, 1860.

Strasser, P., Verbrechermenschen. Zur kriminalwissenschaftlichen Erzeugung des Bösen, Frankfurt/Main, Campus, 1984.

Titzmann, M., Literarische Strukturen und kulturelles Wissen: Das Beispiel inzestuöser Situationen in der Erzählliteratur der Goethezeit und ihrer Funktionen im Denksystem der Epoche, in Schönert, J., (Ed.), Erzählte Kriminalität. Zur Typologie und Funktion von narrativen Darstellungen in Strafrechtspflege, Publizistik und Literatur zwischen 1770 und 1920, Tübingen, Niemeyer, 1991, p. 229-281.

Ulrich, A., «Marie Trottoir» in Zürich. Zur sozialen Situation der Prostituierten in der Belle Epoque, Schweizerische Zeitschrift für Geschichte, 1984, 34, p. 420-430. 
Walkowitz, J.R., Prostitution and Victorian Society. Women, Class, and the State, Cambridge, Cambridge University Press, 1980.

Walser, K., Prostitutionsverdacht und Geschlechterforschung. Das Beispiel der Dienstmädchen um 1900, Geschichte und Gesellschaft, 1985, 11, p. 99-111.

Weininger, O., Geschlecht und Charakter. Eine prinzipielle Untersuchung, Wien, Braumüller, 1903.

Wennmohs, F.A., Uber Gauner und über das zweckmäßigste, vielmehr einzige Mittel zur Vertilgung dieses Uebels, vol. 1, Güstrow, Ebert, 1823.

Wetzell, R.F., The medicalization of criminal law reform in Imperial Germany, in Finzsch, N., Jütte, R. (Eds.), The Prerogative of Confinement: Hospitals and Penal Institutions in Western Europe and North America, 1500-1900, New York: Cambridge University Press, 1997, p. 275-283.

Wilmanns, K., Zur Psychopathologie des Landstreichers. Eine klinische Studie, Leipzig, Barth, 1906.

Wulffen, E., Der Sexualverbrecher. Ein Handbuch für Juristen, Verwaltungsbeamte und Ärzte. Mit zahlreichen kriminalistischen Originalaufnahmen, 8th ed., Berlin, Langenscheidt, 1921.

Zimmermann, G., Die deutsche Polizei im neunzehnten Jahrhundert, 3 vols., Hannover, Schlüter, 1845, 1849.

Zimmerman, K.W., Der sittliche Zustand von Berlin nach Aufhebung der geduldeten Prostitution des weiblichen Geschlechts. Ein Beitrag zur Geschichte der Gegenwart, unterstützt durch die vollständigen und freimüthigen Biographien der bekanntesten prostituierten Frauenzimmer in Berlin, Leipzig, Rührmann, 1846.

Zimmermann, K.W., Die Diebe in Berlin oder Darstellung ihres Entstehens, ihrer Organisation, ihrer Verbindungen, ihres [sic!] Taktik, ihrer Gewohnheiten und ihrer Sprache. Zur Belehrung für Polizeibeamte und zur Warnung für das Publikum, nach praktischen Erfahrungen, Berlin, Reichhardt, 1847. 